\title{
Fish passage assessment at the most downstream barrier of the Ebro River (NE Iberian Peninsula)
}

\author{
Enric Aparicio ${ }^{1,3, *}$, Cristina Pintor ${ }^{2}$, Concha Durán $^{2}$ and Gerard Carmona-Catot ${ }^{3}$ \\ ${ }^{1}$ United Research Services S.L. c/ Urgell 143, 08036 Barcelona. \\ ${ }^{2}$ Confederación Hidrográfica del Ebro. P ${ }^{\circ}$ Sagasta 24-26, 50071 Zaragoza. \\ ${ }^{3}$ Institute of Aquatic Ecology, University of Girona, 17071 Girona, Catalonia, Spain. \\ * Corresponding author: enric_aparicio@urscorp.com
}

Received: 9/11/2010

Accepted: $15 / 4 / 2011$

\begin{abstract}
Fish passage assessment at the most downstream barrier of the Ebro River (NE Iberian Peninsula)

Fish passage at artificial barriers is necessary for the conservation of healthy fish stocks. The first barrier that migratory fish encounter when ascending the Ebro River is the Xerta Weir, where a pool-type fishway was constructed in 2008. From 2007 to 2010, boat electrofishing surveys were conducted in the Ebro River downstream of the Xerta Weir to assess the potential pool of species that could use the fishway. Nine native and 12 exotic species were captured, the latter comprising $62 \%$ of the relative abundance and $70 \%$ of the biomass. A combination of video recording, electrofishing and trapping was used to assess the effectiveness of the fishway in facilitating the passage of fish. Eight species were detected using the fishway, of which five were native (Liza ramada, Anguilla anguilla, Barbus graellsii, Gobio lozanoi and Salaria fluviatilis) and three exotic (Alburnus alburnus, Cyprinus carpio and Rutilus rutilus). Only L. ramada used the fishway in substantial numbers. The rate of fish passage was the highest from June to August and decreased afterwards. The effectiveness of the fishway might be lowered by areas of turbulence within the fishway and by distraction flows from a nearby hydropower station.
\end{abstract}

Key words: Fish movement, fishway, weir, video monitoring.

\section{RESUMEN}

\section{Evaluación del paso de peces en la barrera situada más río abajo en el Río Ebro (NE Península Ibérica)}

El paso de peces a través de barreras artificiales es necesario para la conservación en buen estado de las poblaciones de peces. La primera barrera que los peces migratorios encuentran ascendiendo el Río Ebro es el Azud de Xerta, donde en 2008 se construyó una escala de peces del tipo de estanques sucesivos. Para determinar el conjunto de especies que potencialmente podrían usar la escala se llevaron a cabo muestreos mediante pesca eléctrica desde embarcación aguas abajo del azud. Nueve especies nativas y 12 exóticas fueron capturadas, representando estas últimas el $62 \%$ de la abundancia relativa y el $70 \%$ de la biomasa. Se usó una combinación de grabaciones de video, pesca eléctrica y trampeo para evaluar la efectividad de la escala de peces. Ocho especies fueron detectadas en la escala, de las cuales cinco eran nativas (Liza ramada, Anguilla anguilla, Barbus graellsii, Gobio lozanoi y Salaria fluviatilis) y tres exóticas (Alburnus alburnus, Cyprinus carpio y Rutilus rutilus). Sólo L. ramada usó la escala en un número destacado. La tasa de paso de peces fue más alta de Junio a Agosto y descendió posteriormente. La efectividad de la escala puede estar limitada por areas de turbulencia dentro de la escala y caudales de distracción desde una central hidroeléctrica cercana.

Palabras clave: Movimiento de peces, escala de peces, azud, video, monitorización. 


\section{INTRODUCTION}

The blockage of fish passage due to artificial barriers is one of the main factors negatively affecting the native fish fauna of Spain (Doadrio et al., 1991; Elvira, 1996), especially for diadromous species (Nicola et al., 1996). The impact of barriers on localised movements of riverine fishes is less known, but research suggests that these movements may be significant (RodríguezRuiz \& Granado-Lorencio, 1992; Lucas \& Baras, 2001; De Leeuw \& Winter, 2008). The free passage of fish in river systems is a key objective of the European Water Framework Directive (EC, 2000); therefore, the construction of effective fishways around barriers is necessary to meet these goals. Several designs of fishways are available to enable fish to pass barriers (Clay, 1995); however, most dams and weirs in Spain are impassable to fish (Nicola et al., 1996; Elvira et al., 1998). A further problem is the limited data on the performance of existing fish passes, due, in part, to the high monitoring costs and the low perceived benefits (Kroes et al., 2006). Nevertheless, assessing the effectiveness of fish passes is essential to optimise their operation or make corrections to improve performance. Technical and biological information can also be collected to assist in the development of better designs for future fish passes (Cada \& Sale, 1993). Different techniques are used to monitor the performance of fish passes, such as infrared sensors (e.g., Shardlow \& Hyatt, 2004), echosounders (e.g., Guillard \& Colon, 2000) or radio telemetry (e.g., Larinier et al., 2005), but the high associated costs impose limitations on their use (Kroes et al., 2006). Video monitoring (e.g., Santos et al., 2005) and fish tagging (e.g., Knaepkens et al., 2006) are alternative techniques, but the latter is impractical in large rivers.

The Ebro River drains the second largest Iberian watershed and is one of the largest rivers discharging into the Mediterranean Sea. This river historically supported several species of diadromous fish, but the construction of the Xerta Weir and three large dams in the lower course (Flix, Riba-roja and Mequinenza) created physical barriers that completely blocked upstream movement.
The Xerta Weir is the first barrier that migratory fish encounter when ascending the Ebro River from the sea. In 2008, a fishway was constructed at the weir by the river basin water authorities, and a study to evaluate the fish passage was initiated. The objectives of the study were as follows: (i) to provide information on the fish assemblage of the Ebro River downstream of the Xerta Weir to determine the pool of species that could potentially use the fishway and (ii) to assess the use of the fishway by monitoring the fish passage.

\section{METHODS}

\section{Study area}

The Ebro River is a highly regulated catchment located in the NE Iberian Peninsula that drains $85534 \mathrm{~km}^{2}$ with a total length of $928 \mathrm{~km}$ (Fig. 1). Maximum and minimum mean discharge at the mouth are $682 \mathrm{~m}^{3} \cdot \mathrm{s}^{-1}$ in March and $142 \mathrm{~m}^{3} \cdot \mathrm{s}^{-1}$ in August, respectively. The Xerta Weir, located $56 \mathrm{~km}$ from the river's mouth (Fig. 1), is $310 \mathrm{~m}$ long and $6 \mathrm{~m}$ high and creates an impoundment of $c a .60$ ha. The first weir was constructed during the 15th century to supply water to the rice crops of the Ebro Delta. Two irrigation ditches begin from the left and right sides of the weir, taking up to $50 \mathrm{~m}^{3} \cdot \mathrm{s}^{-1}$ from the river flow. In 2001, a hydropower station was built at the right side of the weir. Most of the flow is conducted to the hydropower station when river discharge is below $400 \mathrm{~m}^{3} \cdot \mathrm{s}^{-1}$ and then is returned to the main river channel $300 \mathrm{~m}$ downstream of the weir (Fig. 1). A fish pass was built in December of 2008 near the entrance canal of the hydropower station (Fig. 1). The fishway is of the pool type (Clay, 1995), is $44 \mathrm{~m}$ long and 2-4 $\mathrm{m}$ wide, and has a set of 14 interconnected pools, with a mean slope of $13 \%$. The water passage from one pool to another is by free surface flow through inclined ramps of $0.4 \mathrm{~m}$ in height. The upstream exit is screened by a metal deflector to prevent floating debris from blocking the pass. The flow through the fishway was variable and depended on the river discharge and turbine operations of the hydropower station, but it usually varied between 
0.5 and $1 \mathrm{~m}^{3} \cdot \mathrm{s}^{-1}$. Water velocities were the highest at the drops between the pools, ranging from 180 to $230 \mathrm{~cm} \cdot \mathrm{s}^{-1}$.

\section{Fish sampling in the river}

From 2007 to 2010, a total of nine electrofishing surveys were conducted along the base of the weir and the river shorelines downstream from the weir to determine the potential pool of species using the fishway (Fig. 1). Fish were collected using an electrofishing unit (Acuitec Erreka III, $2.2 \mathrm{~kW}$ ) mounted in a 3.5-m-long motor-powered boat. Fish captured were identified at the species level, measured (fork length, FL, mm), weighed (g), and released. Abundance and biomass were
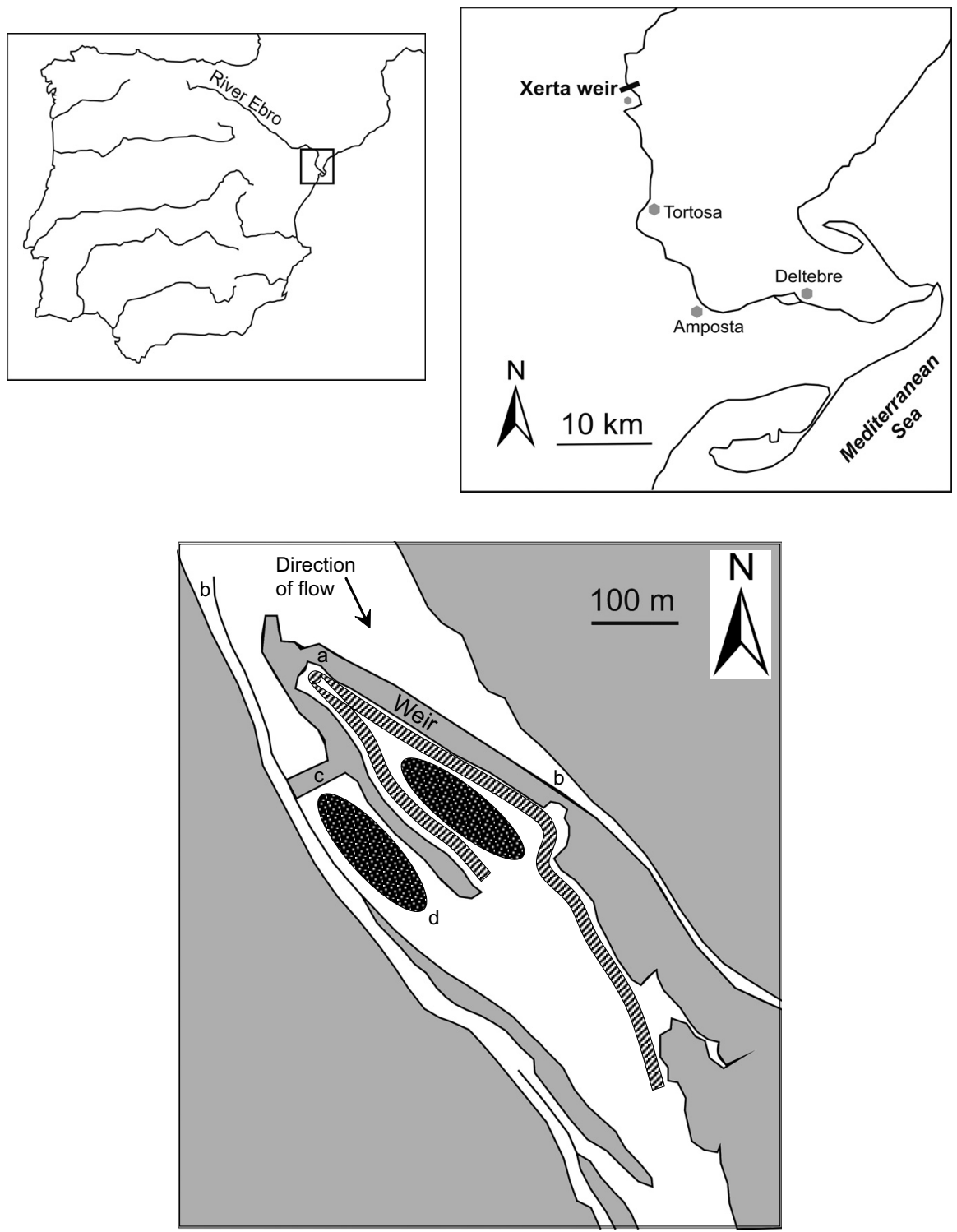

Figure 1. Map of the Ebro River showing the location of the Xerta Weir fishway (a), irrigation ditches (b), hydropower station (c), exit channel of the hydropower station (d), electrofishing sampling sites (shaded areas) and angling sites (dotted areas). Mapa del Río Ebro mostrando la situación del Azud de Xerta, escala de peces (a), canales de riego (b), central hidroeléctrica (c), canal de salida de la central hidroeléctrica (d), localidades de pesca eléctrica (áreas sombreadas) y localidades de pesca con caña (áreas punteadas). 
assessed on a catch-per-unit-effort basis (CPUE, fish ha- ${ }^{-1}$; BPUE, $\mathrm{kg} \mathrm{ha}^{-1}$ ). The total area fished was calculated from the linear distance measured with a global positioning system, assuming the boat fished a transect $2 \mathrm{~m}$ wide. Electrofishing surveys were conducted in April, May and June 2007; May and November 2008; May and September 2009; and May and July 2010. During the same surveys, additional data on species presence were obtained by rod-and-line fishing at the deeper parts of the river where electrofishing was not effective (Fig. 1).

\section{Fish passage assessment}

An underwater video system placed in the upstream end of the fishway was used to mon- itor successful fish passage. The video system consisted of a remote camera with a 1/3" colour CCD at 420 lines of vertical resolution that was equipped with a wide angle lens (model "Look-at", Praesentis, Barcelona). The camera was linked to a computer where the analogue video signal was streamed. Video recordings were taken during daylight hours (09:0019:00 h.) for two consecutive days per month from June to November 2009 and from June to October 2010. The low turbidity of the water (usually $<20 \mathrm{NTU}$ ) allowed for the collection of acceptable video images. Successful fish passage was categorised based on video footage, where the fish that were observed crossing the fishway exit were counted as successful. Time, direction of the movement (upstream or down-

Table 1. Species composition, percentage of occurrence, catch per unit effort (CPUE; Mean and SD), biomass per unit effort (BPUE; Mean and SD) and size (Fork length (FL); Mean, SD and range) of fish captured in the Ebro River below the Xerta Weir during the 2007-2010 study period (Life cycle types: A, anadromous; C, catadromous; F, freshwater; M, euryhaline marine). Composición de especies,porcentaje de ocurrencia,capturas por unidad de esfuerzo (CPUE; Media y SD), biomasa por unidad de esfuerzo (BPUE; Media y SD) y talla (Longitud furcal FL; Media, SD y rango) de los peces capturados en el Río Ebro por debajo del Azud de Xerta durante el período de estudio 2007-10 (Tipos de ciclos vitales: A, anádromo; C, catádromo; F, continental; M, eurihalino marino).

\begin{tabular}{|c|c|c|c|c|c|c|c|c|c|c|c|c|}
\hline \multirow[b]{2}{*}{ Species } & \multirow[b]{2}{*}{ Common name } & \multirow[b]{2}{*}{ Family } & \multirow[b]{2}{*}{ Type } & \multirow[b]{2}{*}{$\begin{array}{c}\% \\
\text { occurence }\end{array}$} & \multicolumn{2}{|l|}{ CPUE } & \multicolumn{2}{|l|}{ BPUE } & \multicolumn{3}{|c|}{$\mathrm{FL}(\mathrm{mm})$} & \multirow[b]{2}{*}{$\operatorname{Max}$} \\
\hline & & & & & fish ha ${ }^{-1}$ & $\mathrm{SD}$ & $\mathrm{kg} \mathrm{ha}^{-1}$ & SD & Mean & $\mathrm{SD}$ & Min & \\
\hline \multicolumn{13}{|l|}{$\overline{\text { Native fish }}$} \\
\hline Alosa fallax* & Twaite shad & Clupeidae & A & - & - & - & - & - & 394.7 & 58.1 & 320 & 510 \\
\hline Anguilla anguilla & European eel & Anguillidae & $\mathrm{C}$ & 100 & 178.0 & 175.5 & 12.70 & 14.63 & 329.9 & 78.0 & 160 & 680 \\
\hline Barbus graellsii & Ebro Barbel & Cyprinidae & $\mathrm{F}$ & 67 & 35.0 & 76.5 & 15.14 & 65.50 & 298.9 & 160.1 & 28 & 605 \\
\hline Dicentrarchus labrax & Sea bass & Moronidae & M & 56 & 4.5 & 9.5 & 5.75 & 22.97 & 353.0 & 131.9 & 229 & 620 \\
\hline Gobio lozanoi & Pyrenean gudgeon & Cyprinidae & $\mathrm{F}$ & 67 & 10.0 & 23.5 & 0.04 & 0.11 & 66.0 & 10.0 & 45 & 78 \\
\hline Liza ramada & Thin-lipped mullet & Mugilidae & $\mathrm{C}$ & 89 & 152.5 & 181.5 & 13.51 & 21.38 & 144.4 & 136.6 & 30 & 500 \\
\hline Mugil cephalus & Striped mullet & Mugilidae & M & 67 & 7.5 & 16.5 & 5.77 & 21.02 & 336.4 & 76.5 & 245 & 460 \\
\hline Salaria fluviatilis & Freshwater blenny & Blennidae & $\mathrm{F}$ & 67 & 13.0 & 38.5 & 0.17 & 0.54 & 94.6 & 20.3 & 67 & 142 \\
\hline Squalius laietanus & Catalan chub & Cyprinidae & F & 22 & 10.5 & 56.5 & 0.07 & 0.36 & 81.6 & 15.1 & 61 & 119 \\
\hline \multicolumn{13}{|l|}{ Alien fish } \\
\hline Alburnus alburnus & Bleak & Cyprinidae & $\mathrm{F}$ & 100 & 349.5 & 416.0 & 1.69 & 2.23 & 67.6 & 15.1 & 28 & 114 \\
\hline Carassius auratus & Goldfish & Cyprinidae & $\mathrm{F}$ & 89 & 16.5 & 41.0 & 11.12 & 36.02 & 298.3 & 64.4 & 155 & 375 \\
\hline Cyprinus carpio & Carp & Cyprinidae & $\mathrm{F}$ & 89 & 18.0 & 29.5 & 48.89 & 82.16 & 496.4 & 202.1 & 28 & 700 \\
\hline Gambusia holbrooki & Eastern mosquitofish & Poecilidae & $\mathrm{F}$ & 78 & 27.0 & 58.0 & 0.02 & 0.04 & 32.6 & 6.7 & 23 & 45 \\
\hline Ictalurus punctatus* & Channel catfish & Ictaluridae & $\mathrm{F}$ & - & - & - & - & - & 366.7 & 25.2 & 340 & 390 \\
\hline Lepomis gibbosus & Pumpkinseed & Centrarchidae & $\mathrm{F}$ & 89 & 66.5 & 117.0 & 1.08 & 1.45 & 86.2 & 26.6 & 40 & 130 \\
\hline Micropterus salmoides & Largemouth bass & Centrarchidae & $\mathrm{F}$ & 67 & 17.5 & 44.0 & 3.72 & 8.25 & 243.2 & 41.7 & 180 & 335 \\
\hline Pseudorasbora parva & Pseudorasbora & Cyprinidae & $\mathrm{F}$ & 100 & 51.0 & 71.0 & 0.15 & 0.22 & 62.5 & 10.4 & 40 & 83 \\
\hline Rutilus rutilus & Roach & Cyprinidae & $\mathrm{F}$ & 67 & 61.5 & 168.5 & 2.25 & 6.55 & 124.1 & 33.1 & 60 & 209 \\
\hline Sander lucioperca & Pikeperch & Percidae & $\mathrm{F}$ & 33 & 10.0 & 29.5 & 0.36 & 1.70 & 101.4 & 61.2 & 63 & 260 \\
\hline $\begin{array}{l}\text { Scardinius } \\
\text { erythrophthalmus }\end{array}$ & Rudd & Cyprinidae & $\mathrm{F}$ & 78 & 28.5 & 60.5 & 0.60 & 1.74 & 100.6 & 55.7 & 53 & 222 \\
\hline Silurus glanis & European catfish & Siluridae & F & 78 & 35.0 & 60.5 & 53.50 & 150.11 & 572.4 & 296.8 & 216 & 1400 \\
\hline
\end{tabular}

* Species only captured with rod and line fishing 
stream) and species of successful individuals was recorded. A visual estimation of the size of passing fish was made by classifying them as small $(<150 \mathrm{~mm}$ FL), medium (150-300 mm FL) or large ( $>300 \mathrm{~mm}$ FL).

The fishway was electrofished immediately after finishing each monthly video recording to obtain information on fish that entered but could not make a successful passage. The sampling was carried out with a backpack electrofisher (1.5 kW, 230-400 V). Because video recordings and electrofishing were conducted at monthly intervals, we assumed that electrofishing did not influence fishway use when the video surveys were conducted. Nocturnal fish passage was also estimated with fyke nets during the same days as video monitoring, from June to August of 2010. Fyke nets were placed blocking the upstream exit of the fishway for one night each month from $20.00 \mathrm{~h}$ to $08.00 \mathrm{~h}$ of the following morning. Fish captured by electrofishing and fyke nets were identified, counted and measured (FL, mm).

\section{RESULTS}

\section{Fish assemblage of the Ebro River}

A total of 1048 individuals representing 19 fish species were collected in the electrofishing surveys below the Xerta Weir from 2007 to 2010. Two additional species and 25 individuals were captured in the deepest parts of the river with rod-and-line fishing. Thus, 21 species were captured during the study (Table 1). Of these, nine (43\%) were native, including three diadromous and two euryhaline marine species, and 12 were exotic (57\%).

The most abundant species in catches were bleak Alburnus alburnus (32\%), European eel Anguilla anguilla (16\%) and thin-lipped mullet Liza ramada (14\%). The highest biomass in the catches corresponded to large-sized species, such as European catfish Silurus glanis (30\%), carp Cyprinus carpio (28\%) and Ebro barbel Barbus graellsii (9\%). Overall, exotic species $(62 \%$ of total CPUE and $70 \%$ of total BPUE) were more abundant in number and biomass than native species (Table 1).

\section{Fish passage monitoring}

A total of 201 fish successfully passed the fishway during the periods of video recording. Of these fish, 183 individuals belonged to four species (thin-lipped mullet, Ebro barbel, eel and bleak), and the remaining 18 individuals could not be identified at the species level. Fish passage observed in the video recordings was dominated by thin-lipped mullet (78\%), followed by Ebro barbel (10\%) (Fig. 2). Electrofishing within the fishway resulted in a total of 76 individuals belonging to the same four fish species found in the video recordings and four additional species (Pyrenean gudgeon Gobio lozanoi, Freshwater blenny Salaria fluviatilis, carp and roach Rutilus rutilus). Thin-lipped mullet was the most captured species by electrofishing (49\%), followed by Ebro barbel (15\%) (Fig. 2). Considering the four species observed in both video recordings and electrofishing samples, their frequencies of occurrence were different among the sampling techniques $\left(\chi^{2}=31.30\right.$, df $=3, P<0.0001)$. Thin-lipped mullet was the only species more frequent in the video record-

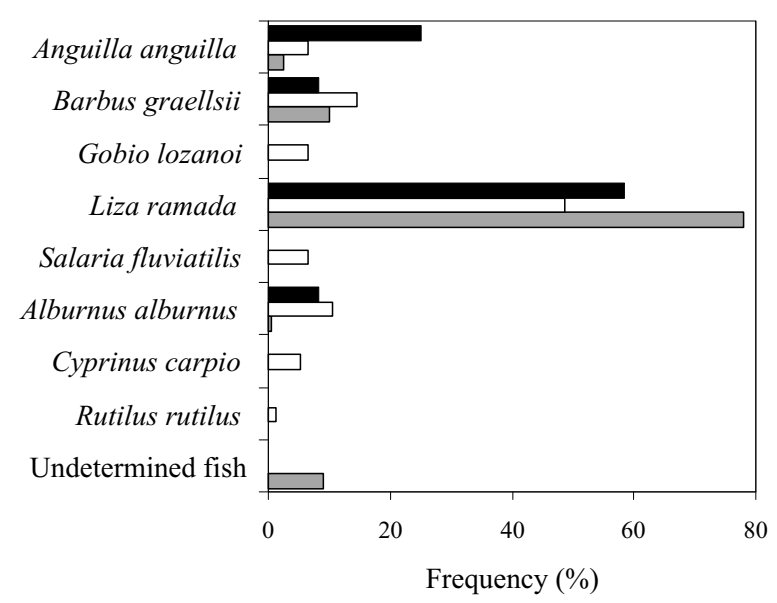

Figure 2. Species composition (in percentage) assessed by video recordings $(N=201$, gray bars), electrofishing $(N=76$, white bars) and fyke nets $(N=12$, black bars) in the fishway of the Xerta Weir during the 2009-2010 study period. Composición de especies (en porcentaje) evaluada mediante grabaciones de video $(\mathrm{N}=201$, barras grises $)$, pesca eléctrica ( $\mathrm{N}=76$, barras blancas) y nasas $(\mathrm{N}=15$, barras negras $)$ en la escala de peces del Azud de Xerta durante el período de estudio 2009-10. 
ings than in the electrofishing catches. Estimates of fish passage at night through the fyke nets recorded 15 individuals belonging to the same four species found in the video recordings (thinlipped mullet, Ebro barbel, eel and bleak). Thinlipped mullet was the most captured species with fyke nets (58\%), followed by eel (25\%) (Fig. 2). The frequency of species occurrence differed between fyke net samples and video recordings $\left(\chi^{2}=34.66\right.$, df $\left.=3, P<0.0001\right)$, which were lower in fyke nets samples for thin-lipped mullet and Ebro barbel and higher for eel and bleak. Summarising the data from the three monitoring techniques used, of the 21 species captured in the river from 2007 to 2010 , eight of them were detected in the fishway. Of these, four species (thinlipped mullet, Ebro barbel, eel and bleak) were observed successfully exiting the upstream end of the fishway, whereas the other four species (Pyrenean gudgeon, freshwater blenny, carp and roach) were captured in the fishway, but we could not confirm that they fully ascended it. Overall, $63 \%$ of species and $88 \%$ of individuals of the total fish detected in the fishway were native.

Most fish passages (94\%) observed in the video recordings were from downstream to upstream. Fish ascending the fishway were of medium size $(150-300 \mathrm{~mm} \mathrm{FL} ; 70 \%)$ or large size (> $300 \mathrm{~mm}$ FL; $30 \%$ ). All fish observed descending the fishway were of small size ( $<150 \mathrm{~mm}$ FL). Electrofishing samples contained a higher proportion of small fish $(<150 \mathrm{~mm}$ FL) compared to the observations in the video recordings $\left(\chi^{2}=42.45, \mathrm{df}=2, P<0.0001\right.$; Table 2$)$.

Temporal trends in the rate of fish passage followed a similar pattern in both years of the study (Fig. 3). Most fish were observed from June to August, with peak passages in July 2009 and in August 2010. Thin-lipped mullet exhibited the highest hourly rates of passage of any species in August 2010 (4.68 fish h${ }^{-1}$ ) and July

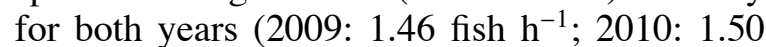
fish $\mathrm{h}^{-1}$ ). Ebro barbel was only observed passing through the fishway in June and July, with the highest rate of passage in June 2010 (0.32 fish $\mathrm{h}^{-1}$ ). No fish were observed ascending the fishway in October and November (Fig. 3). Overall, the hourly rate of fish passage was higher in 2010 (mean 1.96 fish $^{-1}$, SD 2.07) than in 2009 (mean 0.71 fish $^{-1}$, SD 1.01).

\section{DISCUSSION}

\section{Efficiency of the fishway}

The current fish assemblage composition in the lower Ebro River reflects the status of most Mediterranean streams, with a generalised decline of native fish and the progressive invasion of exotics (Aparicio et al., 2000; Clavero \& García-Berthou, 2006; Maceda-Veiga et al., 2010). The native species not collected but historically reported in this area (Sostoa \& Lobón-

Table 2. Number of individuals per size group captured by electrofishing in the fishway of the Xerta Weir, and the number of individuals per size group observed in the video recordings (upstream direction/downstream direction) during the 2009-2010 study period. Número de individuos por grupo de talla capturados con pesca eléctrica en la escala del Azud de Xerta, y número de individuos por grupo de talla observados en las grabaciones de video (dirección ascendente/dirección descendente) durante el período de estudio 2009-10.

\begin{tabular}{|c|c|c|c|c|c|c|}
\hline \multirow[b]{2}{*}{ Species } & \multicolumn{3}{|c|}{ Electrofishing } & \multicolumn{3}{|c|}{ Videos } \\
\hline & $<15 \mathrm{~cm} \mathrm{FL}$ & $15-30 \mathrm{~cm} \mathrm{FL}$ & $>30 \mathrm{~cm} \mathrm{FL}$ & $<15 \mathrm{~cm} \mathrm{FL}$ & $15-30 \mathrm{~cm} \mathrm{FL}$ & $>30 \mathrm{~cm} \mathrm{FL}$ \\
\hline Anguilla anguilla & 0 & 4 & 1 & $0 / 0$ & $0 / 0$ & $5 / 0$ \\
\hline Barbus graellsii & 10 & 1 & 0 & $0 / 12$ & $4 / 0$ & $4 / 0$ \\
\hline Gobio lozanoi & 5 & 0 & 0 & $0 / 0$ & $0 / 0$ & $0 / 0$ \\
\hline Liza ramada & 9 & 23 & 5 & $0 / 0$ & $108 / 0$ & $49 / 0$ \\
\hline Salaria fluviatilis & 5 & 0 & 0 & $0 / 0$ & $0 / 0$ & $0 / 0$ \\
\hline Alburnus alburnus & 8 & 0 & 0 & $0 / 0$ & $1 / 0$ & $0 / 0$ \\
\hline Cyprinus carpio & 0 & 0 & 4 & $0 / 0$ & $0 / 0$ & $0 / 0$ \\
\hline Rutilus rutilus & 0 & 1 & 0 & $0 / 0$ & $0 / 0$ & $0 / 0$ \\
\hline Undetermined & 0 & 0 & 0 & $0 / 3$ & $15 / 0$ & $0 / 0$ \\
\hline
\end{tabular}



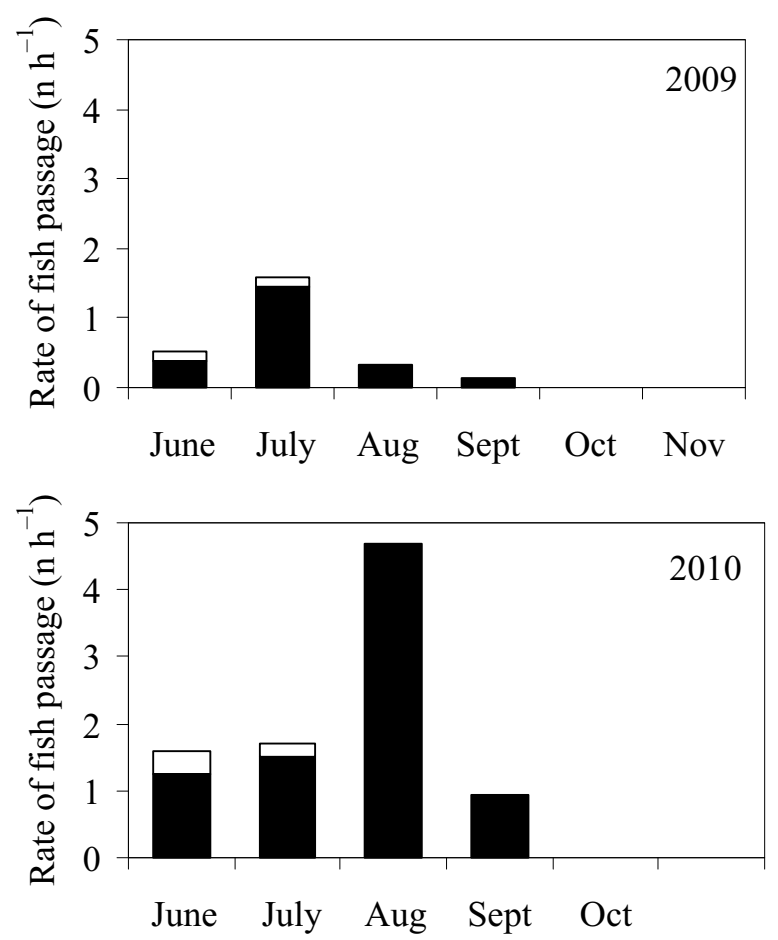

Figure 3. Temporal trends in the hourly rate of fish passage of Liza ramada (black bars) and Barbus graellsii (white bars) in the fishway of the Xerta Weir obtained from video recordings in the 2009-2010 study period. Evolución temporal de la tasa de paso de peces por hora de Liza ramada (barras negras) y Barbus graellsii (barras blancas) en la escala del Azud de Xerta obtenida a partir de las grabaciones de video en el período de estudio 2009-10.

Cerviá, 1989; Doadrio, 2001) include Ebro nase Parachondrostoma miegii and three anadromous species, sea lamprey Petromyzon marinus, European sturgeon Acipenser sturio and allis shad Alosa alosa. These anadromous species are probably extirpated (Porres \& Farnós, 1999; Boquera \& Quiroga, 2001). Ebro nase was formerly common in the main course of the Ebro River, but a sharp decline occurred in the last two decades and this species is now mainly restricted to some tributaries (Sostoa et al., 2010). Although the fish assemblage of the Ebro River was dominated by alien fish, it is noteworthy to remark that the Xerta fishway was mostly used by native fish.

We recorded the presence of eight species in the fishway, but only two, thin-lipped mullet and Ebro barbel, were frequent, and the former was the only one that used the fishway in substantial numbers. Mugilidae species are reported to efficiently use fish passes (Guillard \& Colon, 2000; Santos et al., 2005). The highest rates of passage by thin-lipped mullet at the Xerta fishway were during the summer (July and August) when major upstream migrations of this species occur (Oliveira \& Ferreira, 1997). These findings were in accordance with those of other fishway assessments. For example, Santos et al. (2005) reported that the number of mugilids ascending a fish pass increased in warmer months. Ebro barbel was observed using the fishway only in the spring and early summer, which could be related to potamodromous migration associated with the spawning period (Rodríguez-Ruiz \& GranadoLorencio, 1992; Lucas \& Batley, 1996; Santos et al., 2002). From September to November, the ascension of fish was very low or null, similar to the observations of Santos et al. (2005) elsewhere in the Iberian Peninsula.

The rate of fish passage in the Xerta fishway seemed low when compared to the fish abundances in the Ebro River. Determining the specific causes of passage failure is a complex issue because several factors could have hindered the use of the fishway. For example, the ability of fish to locate the entrance is critical to the success of a fishway in providing fish passage (Clay, 1995; Bunt, 2001). In the Ebro River, fish might have difficulties finding the entrance of the fishway because most of river flow passes through the hydropower station. This diversion might drive most of the upstream migrating fish into the hydropower exit channel, which is located approximately 300 meters away from the fishway. Even if fish find the entrance to a fishway, some might not be able to ascend the full length (Stuart \& Mallen-Cooper, 1999). In our study, small fish were observed using the fishway only in the downstream direction, which suggests that they might not have the ability to fully ascend the structure. The unidirectional, downstream movement of small fish may be due to the high turbulence and water velocities within the fishway, amongst other factors. Similarly, it is likely that the low presence of alien species in the fishway was because of their limnophilic preferences (Leunda, 2010), thus avoiding fast and turbulent waters. 


\section{Implications for native species conservation}

The efficiency of fishways must be assessed under different objectives according to the population dynamics of the species concerned (Porcher $\&$ Travade, 2002). For example, anadromous fish must be able to surmount barriers downstream of their spawning grounds, or else they risk extinction. The persistence of twaite shad following the construction of the Xerta Weir 500 years ago indicates that this species found suitable spawning grounds downstream of the weir (López et al., 2007). However, access to other spawning grounds located upstream from the weir would probably benefit this species (López et al., 2007). The fishway does not seem to accomplish this objective because twaite shad was not observed using the fishway, in accordance with the avoidance of narrow channels and turbulent flow observed for shad species (Larinier \& Travade, 2002). Other connectivity solutions appear to be more appropriate for this species. For example, navigation locks in the Rhone River were adapted to allow twaite shad to surpass weirs (Guillard \& Colon, 2000). We propose that a similar solution in the Ebro River is feasible and demands investigation. For resident freshwater species, a main biological objective is to prevent fragmentation and allow gene flow between conspecific populations. In such a case, a fishway may be considered efficient if it is used by a certain number of individuals and not necessarily by the whole population (Porcher \& Travade, 2002). This goal might be accomplished for Ebro barbel, which was the second most frequent species using the fishway but not for the rest of resident native species, such as Pyrenean gudgeon, freshwater blenny and Catalan chub. Catadromous fish do not require upstream ascent of the Xerta Weir to complete their life cycles. However, the upstream passage of a critical number of individuals could benefit the metapopulation by allowing expansion towards upstream feeding grounds and thus diminishing intraspecific competition in the downstream reaches. This situation may occur with thin-lipped mullet, which was the most frequent species in the fishway. In the case of eel, the low utilisation of the fishway by this species does not appear to influence its upstream presence because it was already abundant above the Xerta Weir before the construction of the fishway (ACA, 2003). Glass eels and elvers are known for their ability to surpass obstacles (Porcher, 2002), and it is likely that they climb the Xerta Weir when weak flows fall over the rough surfaces of the sloping wall.

While upstream passage is important, downstream passage is equally important for fish species attempting to execute their life cycle. However, the fishway recorded only $6 \%$ of fish passage in the downstream direction. The Xerta Weir lacks the facilities to prevent downstream migrants from entering the irrigation ditches and turbine intakes, which poses a risk to fish. For example, high mortalities have been associated with fish subjected to pressure and shear stresses when passing through hydropower stations (Travade \& Larinier, 1992; Hadderingh \& Bakker, 1998). Therefore, a bypass system to safely transport fish below the weir in addition to other solutions to prevent the passage of fish through diversion canals should be considered (e.g., Kynard \& O'Leary, 1993). The restoration of river connectivity in highly altered river systems, such as the Ebro River, should not be viewed as single, independent measures but as a global plan for river continuum restoration (Weyand et al., 2005). Thus, a combination of several different fishways may be required for the efficient passage of fish of a wide variety of species and sizes (Schmetterling et al., 2002). In this context, the Xerta fishway appears to contribute to the connectivity of the lower Ebro River, but other complementary actions are needed to satisfy the biological needs of all of its inhabitants.

\section{ACKNOWLEDGEMENTS}

The authors wish to thank to Miguel Alonso, Xavier Julià, David Piedra, Miquel Torrents and other URS staff for field assistance. Miquel Torrents and Elena Hernández conducted the review of the video recordings. We also thank Antoni and Martí from "Minicentrales DOS" for their assistance and co-operation in the field operations. Brett 
Hanshew, Bruce Hammock and two anonymous reviewers provided comments and suggestions that greatly improved the manuscript. This study was financially supported by the Confederación Hidrográfica del Ebro. GCC held a doctoral fellowship (BR2010/10) from the University of Girona during the preparation of the manuscript.

\section{REFERENCES}

ACA (AGÈNCIA CATALANA DE L'AIGUA). 2003. Desenvolupament d'un index d'integritat biòtica (IBICAT) basat en l'ús dels peixos com a indicadors de la qualitat ambiental dels rius a Catalunya: Conca de la Sènia i de l'Ebre. Generalitat de Catalunya, Barcelona. 65 pp.

APARICIO, E., M. J. VARGAS, J. M. OLMO \& A. DE SOSTOA. 2000. Decline of native freshwater fishes in a Mediterranean watershed on the Iberian Peninsula: a quantitative assessment. Environmental Biology of Fishes, 59: 11-19.

BOQUERA, M. \& V. QUIROGA. 2001. De la saboga al silur: pescadors fluvials de l'Ebre a Tivenys. Generalitat de Catalunya, Departament de Cultura, Barcelona. $141 \mathrm{pp}$.

BUNT, C. M. 2001. Fishway entrance modifications enhance fish attraction. Fisheries Management and Ecology, 8: 95-105.

CADA, G. F. \& M. J. SALE. 1993. Status of fish passage facilities at non federal hydropower Projects. Fisheries, 18: 4-12.

CLAVERO, M. \& E. GARCÍA-BERTHOU. 2006. Homogenization dynamics and introduction routes of invasive freshwater fish in the Iberian Peninsula. Ecological Applications, 16: 2313-2324.

CLAY, C. H. 1995. Design of Fishways and other Fish Facilities. $2^{\text {ond }}$ Ed., Florida: Lewis Publishers. $248 \mathrm{pp}$.

DE LEEUW, J. J. \& H. V. WINTER. 2008. Migration of rheophilic fish in the large lowland rivers Meuse and Rhine, the Netherlands. Fisheries Management and Ecology, 15: 409-415.

DOADRIO, I. (ed.). 2001. Atlas y libro rojo de los peces continentales de España. Segunda Edición. Dirección General de Conservación de la Naturaleza. $364 \mathrm{pp}$.

DOADRIO, I., B. ELVIRA \& Y. BERNAT (eds.). 1991. Peces continentales españoles. Inventario y clasificación de zonas fluviales. Colección Técnica, ICONA, Madrid. 221 pp.

EC (EUROPEAN COMMISSION). 2000. Directive 2000/60/EC of the European Parliament and of the Council of 23 October 2000 establishing a framework for Community action in the field of water policy. Official Journal of the European Coтmunities L, 327: 1-72.

ELVIRA, B. 1996. Endangered freshwater fish of Spain. In: Conservation of Endangered Freshwater Fish in Europe. A. Kirchhofer \& D. Hefti (eds.): 55-61. Birkhäuser Verlag, Basel.

ELVIRA, B., G. G. NICOLA.\& A. ALMODÓVAR. 1998. A catalogue of fish passes at dams in Spain. In: Fish Migration and Fish Bypasses. M. Jungwirth, S. Schmutz \& S. Weiss (eds.): 203-207. Fishing News Books, Blackwell Science, Oxford.

GUILLARD, J. \& M. COLON. 2000. First results on migrating shad (Alosa fallax) and mullet (Mugil cephalus) echocounting in a lock on the Rhône River (France) using a split-beam sounder, and relationships with environmental data and fish caught. Aquatic Living Resources, 13: 327-330.

HADDERINGH, R. H. \& H. D. BAKKER. 1998. Fish mortality due to passage through hydroelectric power stations on the Meuse and Vecht rivers. In: Fish Migration and Fish Bypasses. M. Jungwirth, S. Schmutz \& S. Weiss (eds.): 315-328. Fishing News Books, Blackwell Science, Oxford.

KNAEPKENS, G., K. BAEKELANDT \& M. EENS. 2006. Fish pass effectiveness for bullhead (Cottus gobio), perch (Perca fluviatilis) and roach (Rutilus rutilus) in a regulated lowland river. Ecology of Freshwater Fish, 15: 20-29.

KYNARD, B.\& J. O'LEARY. 1993. Evaluation of a Bypass System for Spent American Shad at Holyoke Dam, Massachusetts. North American Journal of Fisheries Management, 13: 782-789.

KROES, M. J., P. GOUGH, P. P. SCHOLLEMA \& H. WANNINGEN. 2006. From sea to source: Practical guidance for restoration of fish migration in European rivers. EU Interreg IIIC project "Community Rivers". VisAdvies BV, Utrecht. 120 pp.

LARINIER, M., M. CHANSEAU, F. BAU \& O. CROZE. 2005. The use of radio telemetry for optimizing fish pass design. In: Aquatic telemetry: advances and applications. M.T. Spedicato, G. Lembo, G. Marmulla (eds.). Proceedings of the Fifth Conference on Fish Telemetry held in Europe. Ustica, Rome, FAO/COISPA. 295 pp. 
LARINIER, M. \& F. TRAVADE. 2002. The design of fishways for shad. Bulletin Français de la Pêche et de la Pisciculture, 364 suppl.: 135-146.

LEUNDA, P. M. 2010. Impacts of non-native fishes on Iberian freshwater ichthyofauna: current knowledge and gaps. Aquatic Invasions, 5: 239-262

LÓPEZ, M. A., N. GÁZQUEZ, J. M. OLMO-VIDAL, M. W. APRAHAMIAN \& E. GISBERT. 2007. The presence of anadromous twaite shad (Alosa fallax) in the Ebro River (western Mediterranean, Spain): an indicator of the population's recovery? Journal of Applied Ichthyology, 23: 163-166.

LUCAS, M. C. \&E. BARAS. 2001. Migration of freshwater fishes. Blackwell Science, Oxford. 440 pp.

LUCAS, M. C. \& E. BATLEY. 1996. Seasonal movements and behaviour of adult barbel Barbus barbus, a riverine cyprinid fish: implications for river management. Journal of Applied Ecology, 33: $1345-1358$.

MACEDA-VEIGA, A., A. MONLEON-GETINO, N. CAIOLA, F. CASALS \& A. DE SOSTOA. 2010. Changes in fish assemblages in catchments in north-eastern Spain: biodiversity, conservation status and introduced species. Freshwater Biology, 55: 1734-1746.

NICOLA, G. G., B. ELVIRA \& A. ALMODÓVAR. 1996. Dams and fish passage facilities in the large rivers of Spain: effects on migratory species. Archiv für Hydrobiologie Suppl., 113: 375-379.

OLIVEIRA, J. M. \& M. T. FERREIRA. 1997. Abundance, size composition and growth of a thinlipped grey mullet, Liza ramada (Pisces: Mugilidae) population in an Iberian river. Folia Zoologica, 46: 375-384.

PORCHER, J. P. 2002. Fishways for eels. Bulletin Français de la Pêche et de la Pisciculture, 364: 147-155.

PORCHER, J. P. \& F. TRAVADE. 2002. Fishways: biological basis, limits and legal considerations. Bulletin Français de la Pêche et de la Pisciculture, 364: 9-20.

PORRES, A. \& A. FARNÓS. 1999. Evolució al segle $\mathrm{XX}$ de les poblacions d'esturió (Acipenser sturio) al riu Ebre. In: Els esturions (el cas del riu Ebre). J. V. Fernández-Colomé \& A. Farnós (eds.): 93-112. Generalitat de Catalunya, Tarragona.

RODRÍGUEZ-RUIZ, A. \& C. GRANADO-LORENCIO. 1992. Spawning period and migration of three species of cyprinid in a stream with mediterranean regimen (SW Spain). Journal of Fish Biology, 41: 545-556.

SANTOS, J. M., M. T. FERREIRA, F. N. GODINHO \& J. BOCHECHAS. 2002. Performance of fish lift recently built at the Touvedo Dam on the Lima River, Portugal. Journal of Applied Ichthyology, 18: $118-123$.

SANTOS, J. M., M. T. FERREIRA, F. N. GODINHO \& J. BOCHECHAS. 2005. Efficacy of a nature-like bypass channel in a Portuguese lowland river. Journal of Applied Ichthyology, 21: 381-388.

SCHMETTERLING, D. A., R. W. PIERCE \& B. W. LIERMANN. 2002. Efficacy of three Denil fish ladders for low-flow fish passage in two tributaries to the Blackfoot River, Montana. North American Journal of Fisheries Management, 22: 929-933.

SHARDLOW, T. F. \& K. D. HYATT. 2004. Assessment of the Counting Accuracy of the Vaki Infrared Counter on Chum Salmon. North American Journal of Fisheries Management, 24: 249-252.

SOSTOA, A. DE \& J. LOBÓN-CERVIÁ. 1989. Fish and fisheries of the river Ebro: Actual state and recent history. In: Historical changes of large alluvial rivers: Western Europe. G. E. Petts (Ed.): 232247. J. Wiley \& Sons, Chichester.

SOSTOA, A. DE, N. CAIOLA, F. CASALS, E. GARCÍA-BERTHOU, C. ALCARAZ, L. BENEJAM, A. MACEDA, C. SOLÀ \& A. MUNNÉ. 2010. Ajust de l'Índex d'Integritat Biòtica (IBICAT) basat en l'ús dels peixos com a indicadors de la qualitat ambiental als rius de Catalunya. Generalitat de Catalunya, Departament de Medi Ambient i Habitatge, Barcelona. 187 pp.

STUART, I. G. \& M. MALLEN-COOPER. 1999. An assessment of the effectiveness of a vertical slot fishway for non-salmonid fish at a tidal barrier on a large tropical/subtropical river. Regulated Rivers: Research \& Management, 15: 575-590.

TRAVADE, F. \& M. LARINIER. 2002. Monitoring techniques for fishways. Bulletin Français de la Pêche et de la Pisciculture, 364: 166-180.

WEYAND, M., REDEKER M. \& E. A. NUSCH. 2005. Restoration of fish passage: development and results of a master plan established for the Ruhr river basin. Water Science \& Technology, 52: 77-84. 